\title{
Sociological Analysis of Divorce: A Case Study from Pokhara, Nepal
}

\section{Introduction}

This article is based on field study among different caste and ethnic groups residing in Pokhara sub-metropolitan city of Nepal. It tries to identify the causes of divorce in those groups. Probably, it is the first sociological study on divorce based on empirical fact in Nepal, so it may contribute a little bit to the direction of the sociological study. The tradition of sociological and anthropological research on social institutions and processes is not dominant in Nepal. Sociologists have found that there are different natures of changes on social institutions, economy, culture and political structure. This is a universal phenomenon around the world. However it could be fruitful to analyze causes and consequences of the social events or changes from the sociological perspective in the different social and cultural context. This study focuses on divorce basically the legal separation of the husband and wife. However customary divorce practices are in different communities of the Nepalese society.

This study is the result of descriptive, exploratory and analytical research design. Specific goal of the research was to identify the causes of divorce in the context of urban growing city, Pokhara. Main sources of data were judicial court record at first hand identifiying the full address of divorcee and respective lawyers involved in the cases. Interview-schedule, observation, and case study were the methods were employed during data collection. Besides divorcee, their children, family members, intimates, neighbors, lawyers etc were also the sources of data. All cases of divorce, studied, were registered in the district court of Kaski between 1995-1997. Only 80 cases of divorce decrees have been found at that time. Among the eighty decrees cases, 16 cases were from lower caste (Damai, Kami, Sarki and Gaine), 22 cases were from upper caste (Brahaman and Chhetry) and 42 cases were from ethnic groups (Gurung, Magar, Newar, Rai and Tamang). That was the universe of the study. One-third (27 divorced spouses) of the cases were selected from the purposive sampling design due to the guarantees of inclusion of relevant cases for detail study.

I have defined divorce as judicial separation of the spouses and completely disruption of their marital relations. This research has been focused to identify vital causes of divorce under the specific circumstances; socio-economic differentiations, occupational status, family background, role conflict, physical defectives, educational differentiation and legal ground.

\section{Divorce in Social and Cultural Context}

Divorce is the dissolution of marital relations; in this process marriage is completely broken down either in social or legal context. The Black Dictionary of law has defined divorce as "the legal separation of husband and wife affected by the judgment of decree of a court and either totally dissolving the married relations or suspending its effect so far as concern the combination of the practices (1994). Divorcees are free to remarry after divorce where as separation may not allow it. Divorce is nothing and in common senses it is taken easily somewhere in which a couple ends their marital relations and starts to remarry, but it may create some vital problems in the family, like adjusting to new life.

\footnotetext{
- Bala Ram Achrya is a Lecturer of Sociology in Bhaktapur Multiple Campus, Bhaktapur, Nepal
} 
In Hindu society marriage is taken as a holy union between a man and a woman for the performance of religious duties. According to religious philosophy therefore, it is indissoluble and it is for all the birth to come. Divorce itself is a process, which occurs due to different causes of which particularly focus on socio-economic aspect. It has different stages, such as a) Separations-which occurs within family when marital relations is socially broken and clash begins. It is an informal preliminary step of divorce but it is not guaranteed that it leads to divorce. It has probability of reunion between husband and wife, separated couples are not free to remarry b) Desertion-"It is the irresponsible departure from the home on the part of either husband or wife, leaving the family to fend for itself" (M Elliott and Merrill 1950:411), c) Annulment -"It is a court decision that the marriage contains some legal flaw (coercision, fraud, unwillingness to consummate the union, nonage, bigamy) (Goode 1963: 401). This study shows that divorce does not suddenly occur between the spouses. Pre-divorce familial contradictions had arised as found in this study which depended on, immaturity of the partners, cruelty, sexual maladjustment, impotency, quarrelsome disposition of the spouses and other family members, barrenness and, economic dependency that leads to divorce at final stage.

Similarly, the situation of children after the divorce of their parents would face troubles, disturbances and challenges. They would be mentally tortured, Problem of raring and caring of the children may arise due to the absent of their parents, even as the divorcee may be mentally disturbed. Remarriage of the divorced female is very difficult due to social and cultural practices. However, there are different cases of divorce seen in each and every society either in developed or in underdeveloped, secular or non-secular and in different caste and ethnic groups. But this is true that the ratio of divorce found in modern society is higher than previous one. Secular societies are more tolerant and more open for a divorce woman. "The younger generation is increasingly ignorant of the ritualistic basis of their religion (Metha 1975:125). Due to the social and cultural complexities, mobility for job, impact of secularism, global impact of capitalism, emerging legal grounds, of industrialization and urbanization, changing attitudes on traditional norms and value system is causing disintegration of marital relations. Therefore developed and modern societies have more fertile grounds for divorce.

The trend of disintegration and disruptions of family in the west is more significant. The projection of Census Bureau of America, 1990 has predicted that six out of ten American women now in their thirties will go through at least one divorce. For the seventy percent who remarry, fifty two percent will experience a second divorce. According to U.N Demographic Year Book (1994) among total married couple, 4.70 percent of America, 1.36 percent of Japan, and 0.62 Percent of German. 2.96 percent of England and 2.47 of Canada were divorced. However, the trend of marital disruptions in our society is not much more significant as compared to American or European society. In fact, the level of marital adjustment, stability and security with in Nepalese family is becoming loose. However very few empirical data can be found on divorce in Nepalese society due to the customary practices of divorce, which is, disguised forms in every society and socio-cultural restrictions of divorce. Data was taken as combined from on the divorced and separated in the census of 1971,1981 and 1991. According to the census reports $0.28,0.40$ and 0.57 percent were separated and divorced respectively (CBS 1995:179) Population. Family Health Survey took specific data on divorce and separation rate separately in 1996 in which, 0.1percent of people were divorced among one thousand married couple. These trend of data indicated increasing trends of divorce in Nepal. The percentage of divorce rate of the study area under different caste and ethnic group were 40.0 in Gurung, 20.0 in lower caste (Damai, Kami, Sarki and Gaine), 15.0 in Brhamin, 12.50 in Chhetri 5.0 in Newer, 5.0 in Magar, 1.25 in Rai and 1.25 in Tamang (Acharya 1998: 49). Although more than sixty caste and ethnic groups are residing in the city. Among them Gurung, Brhamin, Chhetri, Newar and lower caste people are dominant. Beside legal procedures and practices on divorce, different customary 
practices on divorce can be found in different caste and ethnic groups in Nepal. It assumes that invisible divorced conditions are found in the Nepalese society, which is not legally recognized and practised in the open ground. There are four procedures of customary divorces, which are as follows:

a) Divorce obtained by some formal action: Married couples that are going to be divorced, have to go through some formal actions of divorce by custom in front of their community's assembly or kinsmen assembly, for example -tearing of a 'pan' leaf by both the parities indicates the end of a marriage.

b) Divorce obtained by writing: Divorce which is obtained by writing on the 'Divorce Form' is called 'Dohoro Likhat Gari Chhornu' or' Chhuttanama' or 'Ichhapatra' in local language; all meaning divorce.

c) Divorce obtained by oral pronouncement: This kind of divorce is prevalent among Musalman communities, which are called (i)Talaque-I-Rajai (ii)Talaque-I-bine (ii) Taakaque-I-Mugallja

d) Divorce obtained by "poila" or "Jari" or "Chuman" or "Sagai" form: When a married woman elopes with someone other than her husband, her first marriage automatically breaks down (Thaplia 1995:29-30).Different customary divorce practices and patterns among different caste and ethnic groups in Nepal, which are legally not seen in the public ground can be another crucial research area for sociologists.

\section{Legal System for Divorce}

In the Hindu Society, marriage in the Vedic period (1400-1000 BC) was regarded as a religious sacrament and was indissoluble by human action but Narada and Parasara, the two Smirti writers, had laid down that marriage code be dissolved if the husband was impotent. There were five ground of social sanction where in the wife was allowed to remarry. A woman could take a second husband if the first was missing or dead or had became an ascetic or impotent or was regarded from the ease (Altekar 1980:134) As Kautilya, an ancient Philosopher/economist, has viewed if the husband and wife hated each other, divorce was to be obtained on the ground of mutual enmity. "The Buddhist literature indicates that divorce was rather unusual in the cultured section of the society, women points out her husband that thought she did not love him, she refrained from marring again because it was not the custom in the family for a wedding wife to take new husband"(Altakar 1980: 134). During the medieval period (879-1768) remarriage and divorce for women was not allowed in the higher caste. Beside Hindus, marriage is the sacred social institution among the Christians, whether Catholic or Protestant. According to the Holy Bible the first marriage of human society was performed at the initiative by himself (Pothan 1986:41). However, divorce has been permitted under the special legal provision for Christian. After 1857, the high court of London and after 1912, certain provincial court allowed to grant divorce with adultery as the only ground (Pothan 1986:41). Similarly, the dissolution of Muslim marriage Act VIII of 1939 has been permitted to divorce on special ground. There are some countries even at present where divorce is not permitted by law, e.g. Argentina, Brazil, Chile, Colombia, Eire, Paraguay, Philippines, and Republican Spain (Rheintein 1972:8). In this context, legal provision for divorce in Nepal was clearly declared for both husband and wife by the New Legal Code, 2020 B. S.

In the first written legal code of Nepal (Muliki Ain 1910 B.S.) has permitted a man to leave his wife by the method of sinko-kati chhuttninu(to break a small thin stick of bamboo by husband ), it indicates legal recognition of divorce. Several provisions are made under two separate headings; 1) Parpachuke Garnyako(on Divorce) and 2) Lognya Swasniko Mahal (on the Section of 
Husband and Wife), This legal code has introduced a remarkable change on the women and by the right of divorce and separation. Similarly the section on Husband and Wife in the Naya Muliki Ain ( New Legal Code, 2020 B.S.) which became effective after one hundred and ten years of first legal code of Nepal.The New Legal Code has provide different provisions for divorce on following circumstances:

1. The wife or husband must have resided at separate location for a period of at least three years.

2. Either the wife or husband must have engaged in a conspiracy against the life of the other or have committed a crime of serious physical assault against them, causing grave injuries.

3. The wife is found to have engaged in extra-marital sexual affairs or to have eloped

4 The wife has made a confession in a competent court that she has had sexual relations with somebody besides her husband (Muluki Ain, $10^{\text {th }}$ amendment 2055:135).

If the abnormal behaviors, nonsupport and age barrier in the process of marital relations legal conditions ultimately supports to divorce. It provides justice and way, and ends marital relations legally. In this study, 7.50 percent male divorces were happened due to the barrenness of their wives, which is legally accepted. If a woman does not became a mother in her marital life she is deprived of sacramental right in social life in the context of Hindu traditions, or, the situation creates dissatisfaction, unfaith, contradictions, disparity and non-support among all caste and ethnic groups in Nepal. At the movement, legal provision supports to remarry for the husband. But women are still not able to follow the legal provisions about their husbands impotency it is due to the patriarchal dominations and pressure, although, legally both of them are free. 


\section{Conceptual Framework}

Sociology of family, a new branch of sociology has stressed the changing pattern of social institutions like family, marriage, kinship etc. in the changing context of the society that may differ from society to society. Marital disruptions on the process of separation, desertion, annulment and divorce are very important subject matter to be studied in the sociology of family; however the branch of sociology is not established up to present in Nepal. Every society accepts and supports marriage institution strongly. It is certain that maximum people of marriage age in the society have married or will marry. In the society marriage is seen as a source of support, entertainment and satisfaction to the married couple. However, in real life of family sometimes it falls or breakdown more at modern context. It has some responsible circumstance, like members of society spend less time together to their family than previous, individualism nature of human kind, which leads to marital disruption. At present women are less dependent to men. The situation in the family compelled to husband and wife both to go far from their residence for job, job market becoming wider day by day due to the process of globalization. It generates gap between spouses and the area of interaction becoming wider." Divorce also is more common among couples in which women have successful care, partly due to the stains that arise in twocareers marriage and, more important, because financially independent women are less inclined to remain in an unhappy marriage"(Macionis 1997: 472).

Divorce, from the functional perspective, behavior is largely a response to share norms and values. It, therefore, shows that a change in the rate of marital breakdown is to same degree a reflection of changing norms and values in general, and in particular, those associated with marriage and divorce (Choudhary 1988: 85). As functional perspective, divorce, happening in the society, is a result of adoptive process of spouses who belongs to different socio-economic background and inconsistency of their expectations. Kapadia explains that mental discomfort in joint family is sometimes inevitable as a result of its size, economic strains and consequent bickering, expectations of the younger members and their needs and restrictive, conservative norms laid down by the elders (Kapidas 1966:324). Divorce is not only a social problem, it happens and more influenced in particular socio-economic ground in which existed restrictive social norms and values, which may not be well performed, and raise high expectation between the couples when they married.

Where as Marxian view, different economic background with domination and changing nature of production system, which lead to divorce, may differ from society to society. Marxist Nicky Hart, argue that the increasing divorce rate can be seen as a product of conflict between the changing economic system and its social and ideological superstructures (notably the family)(Choudhary 1988:87). This present research shows when a family members has to go far from house to earn money, then he create gap between his spouses. At that time they are expected to satisfy the biological and economic needs but are unable to fulfill it. The situation leads to contradictions in different level and then occurs divorce. Similarly, the changing nature of occupations, opportunities, earning and investing pattern between the marital partners and their family members may generate role conflict in terms of their status and role.

\section{Family Structure and Divorce}

Joint family or nuclear families are found in most communities of Nepal .It has the cases of marital disruptions in different level and ratio. In my research 55.50 percent of the spouses lived in nuclear families when divorce happened, where as 66.60 percent of spouse lived in joint family during the time of marriage. The reasons of divorce under the nuclear family are sexual or socially gap between the spouses due to the job distance, problem in cohabitation, freedom, out of control from their family, equal status and adjustment problem, education and awareness. In the 
present research 44.50 percent of the spouses lived in joint family during the divorce time. There are different traditions, value systems, and role-performing practices are exercised in joint family structure. New couple may not be satisfied and felt uneasy to adjust and adopt in the joint family guided by traditional practices and value system.

Fonseca 's argument is more or less similar to this research, as her, typical kind of joint family or some cases of the extended family has been the causes for a good deal of conflict and led dissatisfaction among many modern couples (Fonseca 1966:19). In this research, 3.25 divorce cases was occurred due to the barrenness of wife, 7.50 percent of divorce cases occurred due to the family clash between mother- in-laws and sister-in -laws. Similarly, 14.80 percent of wife divorcee had felt irresponsible behavior (lack of raring and caring) performed by husband and other members of their family, where as, 18.50 husband divorcees had blamed to their wives who gave them mental torture and pressure for separation against their interest. Significant numbers of cases were affected by any kind of cruelty by her husband.

\section{Marriage and Divorce}

Marriage is a social and cultural phenomenon and approved social pattern where by two or more persons establish a family. Sexual intercourse between the marital partners and subsumes reciprocal right and obligation between the spouses and their children. Marriage is a key means that enables to make a union between a man and woman, which may situate in different socioeconomic background. However, the forms of marriage are responsible to disruption of marital status and lead to divorce. In the present research 63.0 percent of divorce cases were under the arranged marriage, which may challenge to western divorce trend where, maximum cases of marriage are under love marriage which breakdown easily. Similarly, 37.0 percent of divorce cases are found with in love marriage.

Some of the studies (Choudhary 1988, Pothan 1986, Metha 1975) on divorce based on Indian society have found the causes of divorce leads by exogamy marriage but in this study 8.40 percent of divorce cases have found under endogamy marriage system. Basically, low age at marriage of wife, marriage with wrong information or forced marriage. 7.40 percent of educated women were married with illiterate men without any concerned to her; they were actually unknown about it. In this study as a case, Mr. S.A and miss P.R were married with wrong information. Basically that was based on their family interests. She was matrix pass where as her husband was just literate but relatively well in economic condition. After two years of their marriage, marital relation between them was continuously became loose and occurred divorce. Similarly, unequal educational and economic statuses of the spouses were major cause of the divorce under arranged marriage, which has more or less endogamy nature. Similarly, 33.0 percent of male were generally disagreed on the process of their marriage. 7.40 percent married were exogamy, which failed to gain family support. Those marital circumstances have created the situation that supports to breakdown their marital relation. 33.0 percent of husbands and 60.0 percent of wives were at the age of 20 when they get married. This situation of age factor indicates that the divorcee had immaturity to their family life. Similarly, the high age difference in husband and wife and unequal educational status creates differ expectations from the marriage which strongly support to occur divorce gradually.

\section{Occupation and Divorce}

The nature of occupations of the people is determining the social and economic status. It affects the individual behavior. The occupational mobility of the spouses makes relations broad. Therefore family relations would becomes weak due to the frequently met and appropriate 
familial raring and caring. " Divorce is relatively high among persons engaged in occupation necessitating frequent absence from home, involving, intimate contact with the opposite sex, and controlled relatively little by the community" (Burgess and Locke 1950: 634). The present findings of the research moderately supports to the research arguments of Burgess and Locke (1950:569). In the present research findings 25.90 percent of husbands and 22.20 percent of wives were engaged in job. Similarly, 11.10 percent husbands and 7.40 percent of wives were engaged in business. 14.80 percent of husbands and wives were involved in agriculture, 11.10 percent of husbands and 3.70 percent of wives, beside house- wife were jobless and unemployed.

The research findings show that only the occupational status is not responsible causal factor for divorce .In the study 29.60 percent husbands and wives were involved either in agriculture or wage labor or self-employed. The event of divorce is not emotional and based on specific occupational statuses rather it is affected by different socio-economic relations. However, if the situation support to being far from each other and close relations to opposite sex among the spouses due to the causes of occupational performance or mobility, it support to causal circumstances for divorce, which signified by the present study.

\section{Economic Condition and Divorce}

Economic aspect is the crucial, dominant and effective component of the society. Every happiness, trust, support and sympathy or tension, clash, quarrel, and maladjustment or marital incompatibility in the family is the causes of economic factors. The divorce rate is found higher if spouses have more expection from each other, faced economic hardship and gone far from their residence due to the economic achievement. Burgess and Cottrell (1950:569) have found that specific economic items such as moderate income, savings, and occupation characterized by stability and social control and regularity and continuity of employment were individually correlated with happiness scores. In the present study, 18.50 percent of the wife divorcee had felt economic crisis, it means they are unable to regulate their daily household expense, problems in their children schooling, unable to fulfill their personal requirement as a wife and took decision for divorce. They blamed that their husbands were really unable to regulate household properly. But divorced women had better economic condition than their husband and more freedom than before married.

Similarly, 7.40 percent of husband who had gone foreign job felt their wives had irresponsible economic management and intentionally misuse huge amount of money gained by him. They blamed that their wives create luxurious life style and engaged with boy friend. Due to the economic causes two lower caste female were married with foreigners with contact basis which easily breakdown later. Similarly, one male had married with foreiners; at that time he had got divorce with her previous wife and wanted to accumulate much more money from foreign wife. It is interesting to note that he was not really divorced with her previous wife, at the same time he was frequently sent huge amount of money from aboard and got reunion after two years. In the present study, two men got second marriage with foreign women and made artificial divorce paper to her previous wives. Similarly, the trends of artificial divorce were found in Pokhara city to get ID card for Hong Kong and Britain due to the legal barrier to get married with ID holders, which is also not real. As Pothan (1986) dowry has become an inseparable of marriage in India. However, present study has found that the effect of dowry system is not directly signified on divorce. Although Nepalese society, mostly high caste people and people of Tarai region of Nepal is seriously affected by this system.

\section{The level of Educational Attainment and Divorce}


Inequality in education between the spouses creates different ideas about their lives, ways of thinking and expectations. Therefore education is an important decisive factor in rating marital relationships either happiness or creates aware. In this research, the level of education of women was found low in comparison to men. However the findings of the study shows that the level of divorce was found in different level of educational background. The research findings supports to the findings of Kapida. He argued that it is not possible to predict whether educations exercise any restraining or corrective influence with regard to divorce (Kapida 1966:298). Educational condition is performed multidimensional role whether occurred divorce or compatibility in marital relations. But impact of education able to collect strength and ideas against injustices and raises more expectations and ambitions.

This study shows, 7.40 percent of illiterate husbands and 11.10 percent of illiterate wives were involved in divorce, where as 7.40 male divorce were graduate. More than 50 percent of divorce cases both male and female were under matrix .In this study one marriage case was under at marriageable age and another one was forced marriage which were breakdown later due to the educational empower which enable them to use legal right. In Nepal, according to New Legal Code 2020 and its $10^{\text {th }}$ amendment has fixed marriageable age. As per the provision 16 years for girls and 18 years for boys provided the parents' consent is obtained. Similarly 18 years for girl and 21years for boys, if the parents' consent is not obtained. The differences between women and men legally should not exceed 20 years. In this context, sister-in-law or wife or women in the family aware about their right and opposed to exploitations, cruelty and oppression due to the educational awareness and able to go to court for divorce but, it is very difficult to examine the level and quantity of impact of education on divorce. Terman arise two questions with regard to the influence of education on a couple, the first is the relation of happiness to the extent of education that a spouse had, and the second is the difference in educational status between the spouses (Terman 1938:187) Similarly, the research concludes that educational level between husband and wife is a stimulating factor for divorce.

\section{Conclusion}

Divorce is multidimensional and it involves multifactor social events. It can be found in each and every society, which may be either in customary, or in legal form. Basically it occurs easily within more open and industrial society. It is emerging a form of new sociological events due to the pattern of socio-cultural changes by the process of modernization and simultaneously urbanization. In our context it should be sociologically investigated. This study has been an attempt to identify the causes of divorce, which provides sociological insight to further researcher. The pattern of divorce in this study is diverse and it is found in each community even in Hindus, in which marriage is taken for life or it is for after death, therefore divorce and remarriage is not culturally and socially accepted in the almost all Hindu dominant Nepalese society where nearly eighty percent people belongs to Hindu religion.

Single causal factor is not responsible for dissolution of marriage. Different natures of dissatisfactions between the spouses are affecting due to the personal, familial, social and economic condition or structure. Therefore, it should be treated under the multidimensional approach basically in the reference to contemporary changing socio-cultural pattern. In this findings, economic hardship and ambitious, cruelty, sexual maladjustment, wife barren, unequal social, educational and economic status, and more expectations by the spouses after marriage are the major causes of marital disruption. Occupational mobility and the situation of agreement to the opposite sex, low age at marriage and immaturity, adjustment problems of new wives, traditional and modern expectations between the mother-in-law and sister -in-law are found as causal factors in the present study. Similarly, legal provisions for divorce supports such kind of 
spouses who are felt very uneasy to stay together in the family. The natures of causes are differing from men to women. Divorce is not only the end of marital relations between the spouses rather it has caused serious problems on their children and adjustment problems themselves in the community. There are different divorce cases, which are not found in the court record in visible form due to social, cultural and economic constraints. Therefore it is essential to examine and analyze customary divorce practices, which found in each and every community.

This article is based on the author's empirical study for his Masters degree dissertation writing, on the topics of Marriage and Divorce in the Nepalese Society, A Case study of Pokhara SubMetropolitan City in 1997-1998.

\section{References}

Acharya, Bala Ram, 1998: Mariage and Divorce in Nepalese Society, A Sociological Study, (Unpublished Masters' Degree Dissertation),

Altakar, A.S., 1980: The Position of Women in Civilization, Bombay; Allied Publishers

Altekar Indra Deva, 1980: Growth of Legal System in Indian Society, Bombay, Allied Publishers,

Burgess, Ernest W. And Locke, J. 1950: The Family, American Book Co., New York

CBS1995: Population Monograph of Nepal, 1995

Choudhary, J.N. 1988: Divorce in Indian Society, A Sociological Study of Marriage Disruption and Role Adjustment

Fonseca, Mabel .B, 1966: Consoling for Marital Happiness, Harper and Brothers, New York

Goode, William J. 1963: Family Disorganization in Contemporary Social Problem (ed) R. K Merton\& Robert A Nisbet, London

Kapidas, K.M 1966: Marriage and Family in India, London Oxford University Press,

Mabel, A Elliott and Francos,E Merrill, 1950: Social Disorganization, third edition ,Harper and Brothers, New York

Macionis, John J, 1997: Sociology, Sixth Edition, Prentice Hall, and Upper Saddle River, New Jersey

Metha Rama, 1975: Divorced Hindu Women, Vikash Publishing House Pvt., and New Delhi.

Metha Rama, 1975: Divorced Hindu Women, Vikash Publishing House, Delhi,

Muluki Ain 2055 10th amendment, Kanun Kitab Byabasta Samiti,Babar Mahal Kathmandu

Pothan, S (1986): Its Causes and Consequences in Hindu Society, Vikash Publishing House, PVT, LTD India.

Rheintein, Max 1972: Marriage Stability, Divorce and the Law

Sangraula Youbaraj and Pathak Gita, 2002: Gender and laws, Nepalese Perspective, Pairavi Prakashan, Kathmandu

Schultz Emily \& Lavenda Robert H, 1995: Anthropology, A Perspective on the Human Condition, Second Edition, Mayfield Publishing Company. London

Sweet, James A. and Larry L. Bumpass, 1987: American Families and Household, Russell Sager Foundation, New York

Terman, L.M., 1938: Psychological Factors in Marital Happiness, McGraw Hill Book, Co., New York

Thaplia, Santa, 1995: Customary Practices of Divorce in Nepal, Legal Aid and Consultancy Center, LACC, Pulchowk

Thorns, Barbara and Jean Collard, 1979: Who Divorce? Marriage Research, Central Middlesex Hospital, Rutledge and Kegan Paul London 